\title{
Identifying blue swimming crab (Portunus pelagicus) stocks with truss network analysis approach in Indonesian Fisheries Management Area 712
}

\author{
Nurhaya Afifah ${ }^{\mathrm{a}}$, Zairion Zairion ${ }^{\mathrm{bc}}$, Hawis H. Madduppa ${ }^{\mathrm{d}}$, Agus A. Hakimc, Yusli Wardiatno ${ }^{\text {bce }}$ \\ ${ }^{a}$ Master Program in Coastal and Marine Resources Management, Graduate School of IPB University, Kampus IPB Darmaga, Bogor \\ 16680, Indonesia [+62 81295380728] \\ ${ }^{\mathrm{b}}$ Center for Coastal and Marine Resources Studies, IPB University, Kampus IPB Baranangsiang, Bogor 16143, Indonesia \\ ${ }^{c}$ Department of Aquatic Resources Management, Faculty of Fisheries and Marine Sciences, IPB University, Kampus IPB Darmaga, \\ Bogor 16680, Indonesia \\ ${ }^{\mathrm{d}}$ Department of Marine Science and Technology, Faculty of Fisheries and Marine Sciences, IPB University, Kampus IPB Darmaga, \\ Bogor 16680, Indonesia \\ ${ }^{\mathrm{e}}$ Environmental Research Center, IPB University, Kampus IPB Darmaga, Bogor 16680, Indonesia
}

\section{Article Info:}

Received: 01 - 05 - 2020

Accepted: 15 - 06 - 2020

\section{Keywords:}

Discriminant analysis, fisheries management, Java Sea, morphometric, Portunidae

Corresponding Author: Yusli Wardiatno

Department of Aquatic Resources Management, Faculty of Fisheries and Marine Sciences, IPB University; Tel. +62-251-8622932

Email:

yusli@apps.ipb.ac.id

\begin{abstract}
The exploitation rate of the blue swimming crab (BSC) in Indonesian Fisheries Management Area (FMA) 712 is over-optimum level in 2016. Stocks concern in sustainable management is needed as an effort to maintain its availability. The objective of this study is to identify the stock unit of BSC based on Truss Network Analysis (TNA) of morphometric characters in FMA 712. The BSC was collect in five different locations, i.e. East Lampung, Lancang Island, Cirebon, Rembang, and Southern Madura. Measurements on TNA were carried out at 14 landmark points with 29 characters in carapace to analyze its morphometric characters. The cluster analysis showed that TNA method revealed two stocks units of BSC in FMA 712. The first stock was the BSC population of Southern Madura, and the other stock was the other four populations. The longest Euclidean distance was found at Southern Madura indicating similarity level with other populations was low. The discriminant analysis demonstrated different results. There were three group populations, in which every population in one group were able to represent the other population, namely Lancang Island-Cirebon, East Lampung-Rembang, and Southern Madura. Regarding this study, it is recommended to manage BSC in Southern Madura separately.
\end{abstract}

How to cite (CSE Style $8^{\text {th }}$ Edition):

Afifah N, Zairion Z, Maduppa HH, Hakim AA, Wardiatno Y. 2020. Identifying blue swimming crab (Portunus pelagicus) stocks with truss network analysis approach in Indonesian Fisheries Management Area 712. JPSL 10(3): 390-401. http://dx.doi.org/10.29244/jpsl.10.3.390-401.

\section{INTRODUCTION}

In general, order Decapoda has become a lot of research objects in Indonesia, including blue swimming crab (Hamid et al., 2015; Hamid and Wardiatno, 2015; Zairion et al., 2015a, 2015b; Hamid et al., 2016a; Kembaren et al., 2018; Zairion et al., 2020) because of its high economic value (Prabawa et al., 2014; Jayawiguna et al., 2017). Distribution areas of these species are along northern Java and east Lampung. The region is incorporated in the 712 State Fisheries Management Areas (FMA) of the Republic of Indonesia and is an area that intensively provides the highest foreign exchange earnings for crab export fisheries. Based on Statistics Indonesia (2018), Indonesian crab exports reached 29038 tons in 2015 and the total volume of Indonesian crab exports was 15867 tons in 2017 (MMAF, 2018). It's similar with other countries which 
demand for crab in international trade has increased (Wiyono and Ihsan, 2015). Along with efforts to increase the yield of crab fisheries, it is necessary to have sustainable crab management in order to decline increased fishing activity that has the potential to cause a decrease crab population (Wiyono and Ihsan, 2018).

Attempt to manage fisheries resources cannot be generalized in each region. According to FAO (1995), one important thing that must be considered in management is the stock of its resources in order to maintain a balance of utilization and conservation. Each population stocks usually characterized by the specific biological attributes (Secor, 2014). The differences can be seen through phenotype, genetic (Aini et al., 2020), or both simultaneously (Hollander and Butlin, 2010). A particular geographical area can be said to have different stock units or have been declared geographically separated from each other if the character of growth, mortality, meristic and morphometric characteristics, and genetic are different in a relatively long time (Hart and Reynolds, 2002). The concept explains that important tool for identifying stocks and evaluating the population structure can be done with morphometric characterization techniques (Rawat et al., 2017; Sajina et al., 2011; Sen et al., 2011), in more detail, namely the truss network approach (Bhosale et al., 2018). The truss network approach has emerged as a new tool for understanding population structure in many fish species with more effective strategies for descriptions of shape, better data collection and diversified analytical tools (Pazhayamadom et al., 2015). This characterization technique is more effective than manual distance measurement for the management of fishery resources throughout the world because truss networks are able to show increased ability to identify differences in the morphological shapes of the bodies of each species (Mojekwu and Anumudu, 2015). Using truss network approach in determining the stock structure of aquatic species has been started from the $20_{\text {th }}$ century. This method is applied in several crustacea studies, including shrimp (Paramasivam et al., 2017; Marini et al., 2017; Rebello et al., 2013), and in BSC (Bhosale et al., 2018).

Data and information about the crab stock structure in morphometric FMA 712 have not been much studied. However, the exploitation rate of BSC in northern Java waters has exceeded the level of sustainability or is in the overexploited stage due to the Ministry of Marine Affairs and Fishery Decree No. 70/2016. Therefore, it is expected that the results of a morphometric analysis can be an input for the management of crab fisheries stocks as an effective, optimal, and sustainable crab resource management concept. The main objective of this study was to identify BSC stocks based on morphometric characters with truss network analysis in FMA 712.

\section{METHOD}

\section{Location and Specimen Collection}

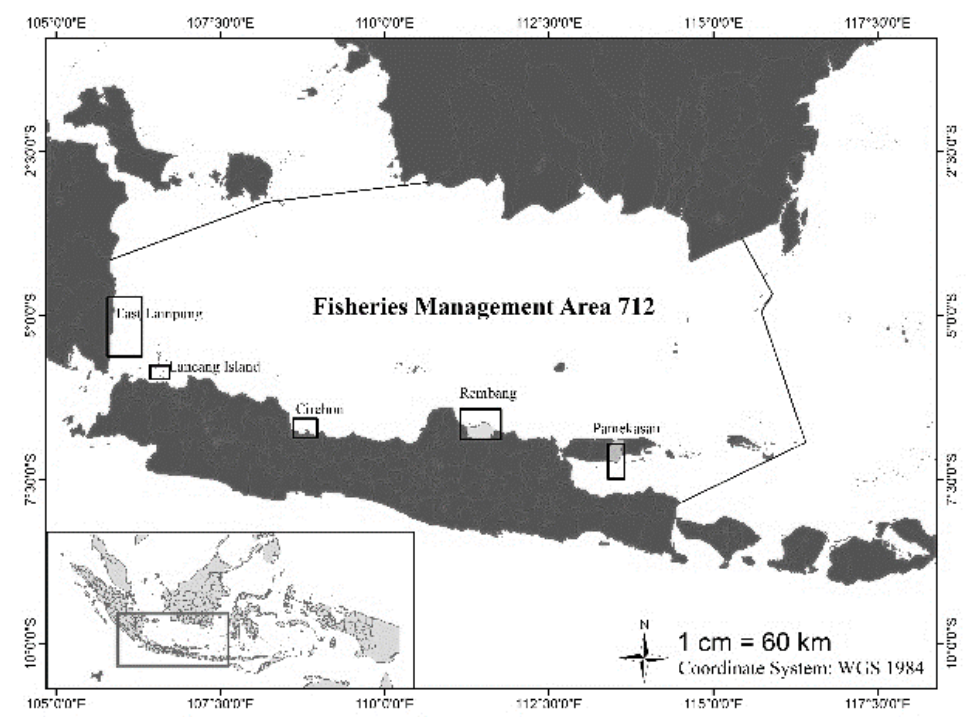

Figure 1 Sampling location of the blue swimming crab (Portunus pelagicus) in Fisheries Management Area 712 as indicated by the open-black rectangles 
Portunus pelagicus samples were collected from five locations, namely East Lampung, Lancang Island, Cirebon, Rembang, and Southern Madura to represent FMA 712 (Figure 1). Sampling of various sizes was done randomly from the local fishermen. A total of $476 \mathrm{crab}$ individuals were taken from all location and analysed at the laboratory.

\section{Digitizing Sample}

Each individual carapace of a BSC sample was separated from the rest of the body and then cleaned and dried using a tissue to analyze its morphometric characters using truss network analysis. Carapace samples were placed on a flat platform with scaled vertical and horizontal grids for easy calibration of digital image coordinates. The distance between vertical and horizontal grids covers an area of $1 \mathrm{~cm}^{2}$. The tagging was then carried out on each individual according to a predetermined landmark. The digitization phase was conducted in order to become an archive for repeated measurements. Measurements on TNA were carried out at 14 landmark points with 29 characters in carapace (Bhosale et al., 2018). These landmark points were presented in Figure 2. Labeling was done on each grid paper as a marker of the sample order. The crab was then photographed with a camera with the help of a modified tripod (Marini et al., 2017). Furthermore, all images of digitized could be identified based on the tagging attached.

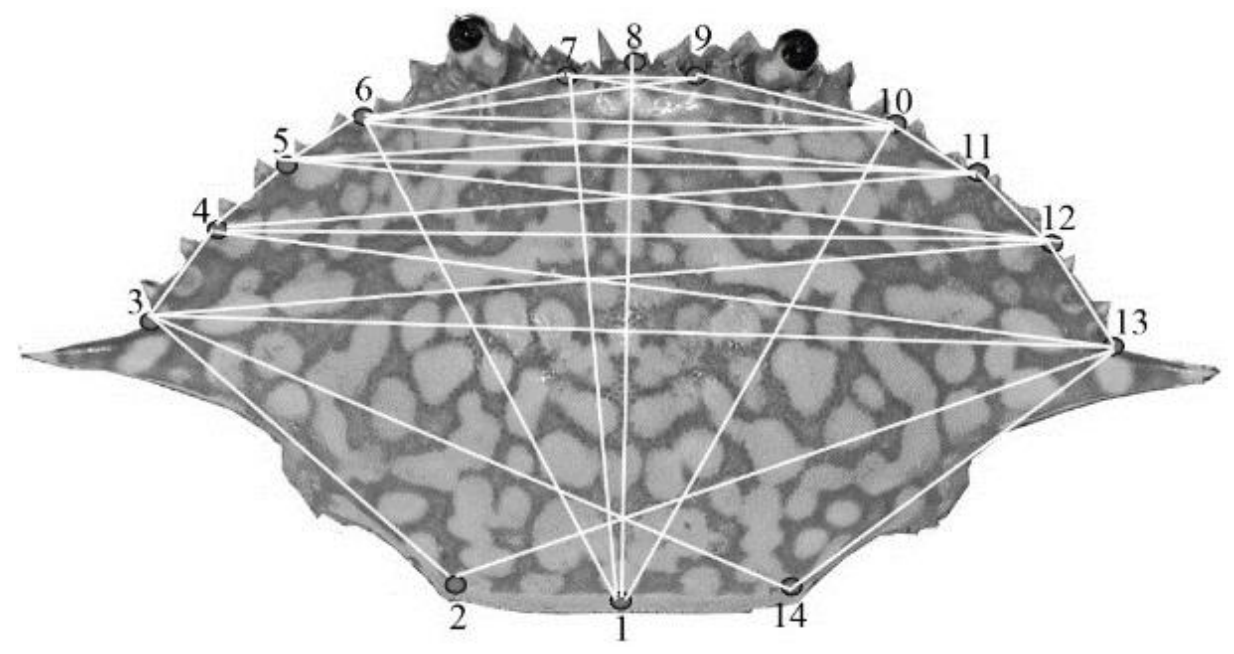

Figure 2 Landmark truss network analysis for the blue swimming crab (Portunus pelagicus)

\section{Morphometric Truss Measurements}

Morphometric character measurements with truss network analysis were performed using a combination of two software, TPSUtil V1.38 and TPSDig2 V2.1 software series (Rohlf, 2006) and Paleontological Statistics (PAST) which were used to extract morphometric data from each image (Hammer et al., 2001). All images were first converted from JPEG (*. jpeg) to TPS format (*. tps) using TPSUtil. The TPSDig2 was used for digitizing landmarks and provided an outline of the distance of landmarks on the image object for geometric morphometric analysis of objects. The encrypted tps format image file description data was utilized as an input source in PAST, which was useful for multivariate analysis and paleontological modeling (Bhosale et al. 2018). Then the crab morphometric points were measured with morphometric truss, which theoretically could improve accuracy in differentiating morphometrics among samples. The variables extracted from sample digital images by interconnecting 14 landmarks to form 29 distance variables, as presented in Table 1 . 
Table 1 Landmarks, codes, and description used in the morphometric truss of the carapace for the present blue swimming crab (Portunus pelagicus) study

\begin{tabular}{|c|c|c|}
\hline Landmark & Code & Descriptions \\
\hline $1-8$ & UP1 & The midpoint of the abdomen to middle teeth on the forehead \\
\hline $3-13$ & UP2 & Between first anterolateral teeth \\
\hline $4-12$ & UP3 & Between third anterolateral teeth \\
\hline $5-11$ & UP4 & Between fifth anterolateral teeth \\
\hline $6-10$ & UP5 & Between seventh anterolateral teeth \\
\hline $7-9$ & UP6 & Between antennule \\
\hline $1-7$ & UP7 & The midpoint of the abdomen to left antennule \\
\hline $2-13$ & D1 & The left abdomen to first teeth of the right anterolateral \\
\hline $3-14$ & D2 & The first teeth of the left anterolateral to the right abdomen \\
\hline $4-13$ & D3 & The third teeth of the left anterolateral to the first teeth of the right anterolateral \\
\hline $3-12$ & D4 & The first teeth of the left anterolateral to the third teeth of the right anterolateral \\
\hline $5-12$ & D5 & The fifth teeth of the left anterolateral to the third teeth of the right anterolateral \\
\hline $4-11$ & D6 & The third teeth of the left anterolateral to the fifth teeth of the right anterolateral \\
\hline $6-11$ & D7 & The seventh teeth of left anterolateral to the fifth teeth of the right anterolateral \\
\hline $5-10$ & D8 & The fifth teeth of the left anterolateral to the seventh teeth of the right anterolateral \\
\hline $7-10$ & D9 & The left antennule to the seventh teeth of the right anterolateral \\
\hline $6-9$ & D10 & The seventh teeth of the left anterolateral to the right antennule \\
\hline $2-3$ & L1 & The left abdomen to the first teeth of the left anterolateral \\
\hline $13-14$ & L2 & The first teeth of the right anterolateral to the right abdomen \\
\hline $3-4$ & L3 & The first teeth of the left anterolateral to the third teeth of the left anterolateral \\
\hline $12-13$ & L4 & The first teeth of the right anterolateral to the third teeth of the right anterolateral \\
\hline $4-5$ & L5 & The third teeth of the left anterolateral to the fifth teeth of the left anterolateral \\
\hline $11-12$ & L6 & The third teeth of the right anterolateral to the fifth teeth of the right anterolateral \\
\hline $5-6$ & L7 & The fifth teeth of the left anterolateral to the seventh teeth of the left anterolateral \\
\hline $10-11$ & L8 & The fifth teeth of the right anterolateral to the seventh teeth of the right anterolateral \\
\hline $6-7$ & L9 & The seventh teeth of the left anterolateral to the left antennule \\
\hline $9-10$ & L10 & The right antennule to the seventh teeth of the right anterolateral \\
\hline $1-6$ & L11 & The midpoint of the abdomen to the seventh teeth of the left anterolateral \\
\hline $1-10$ & L12 & The midpoint of the abdomen to the seventh teeth of the right anterolateral \\
\hline
\end{tabular}

\section{Data Analysis}

Morphometric truss measurement results were all transformed based on data normality characteristics. Data were transformed by eliminating all things affecting size by using the allometric approach from the modified formula of Hurlbut and Clay (1998) and Ihsen et al. (1981), namely:

$$
\text { Mtrans }=\log \mathrm{M}-\beta(\log \mathrm{SL}-\log \text { SLmean })
$$

Where:

Mtrans : truss measurement transformation

B : the within-group slope regressions of the $\log \mathrm{M}$ vs $\log \mathrm{SL}$

M : truss measurement

SL : length of crab carapace

SLmean: average crab carapace length in each population 
Morphometric data with both methods were analyzed using SPSS software version 15 . The transformed truss measurements were subjected to Kruskal Wallis analysis, cluster analysis, and classification by crossvalidation of discriminant analysis. The Kruskal Wallis test was used to find out the distinguishing characteristics of morphometric characters which differed significantly in the crab group in five locations (Ostertagova et al., 2014). The grouping of similar members in one population in BSC could use cluster analysis assuming that certain amounts of data had a level of morphometric similarity between populations. This numerical analysis was used to classify organism based on its systematics (Smith et al., 2011). Cluster analysis was performed using the average morphometric data of the BSC measured from each location. The results obtained were dendrogram trees based on euclidean distances. This distance explained the level of kinship between populations. The greater the value of the euclidean distance, the lower the kinship between populations. Conversely, the smaller the value of the euclidean distance, the higher the kinship between populations. Variations in BSC morphometrics in this study were analyzed using Discriminant Analysis (DA). The discriminant analysis was performed to determine groupings and test the equality of group (Hidayani $e t$ $a l ., 2015)$. This analysis examines and describe simultaneously the differences between two or more mutually exclusive groups. The results obtained were in the form of a sketch population distribution plot of the five study sites.

\section{RESULTS AND DISCUSSION}

A total dorsal carapace of 235 males and 240 females were used and combined as one in the analysis. Detailed information on the collected BSC is summarized in Table 2.

Table 2 Sex ratio of blue swimming crab collected from five sampling points of FMA 712

\begin{tabular}{lcccc}
\hline \multirow{2}{*}{ Sampling Site } & $\begin{array}{c}\text { Number of } \\
\text { Samples }\end{array}$ & Male & Fex & $\begin{array}{c}\text { Sex Ratio } \\
\text { (Male/Female) }\end{array}$ \\
\cline { 3 - 4 } East Lampung & 99 & 59 & 40 & $1: 0.680$ \\
Lancang Island & 106 & 49 & 57 & $1: 1.163$ \\
Cirebon & 92 & 21 & 71 & $1: 3.381$ \\
Rembang & 73 & 24 & 49 & $1: 2.042$ \\
Southern Madura & 105 & 82 & 23 & $1: 0.281$ \\
Total & 475 & 235 & 240 & \\
\hline
\end{tabular}

\section{Normality Test}

The normality test was an important step for deciding the measures of central tendency and statistical methods for data analysis (Mishra et al., 2019). Data normality was tested using the Kolmogorov-Smirnov (2tailed) test (Ghasemi and Zahediasl, 2012). These test results were the significance value of the SPSS output results. The significance value $(\alpha>0.05)$ indicated data that are normally distributed. The test was carried out on all morphometric data of male and female swimming crab at five locations. All male and female swimming crab characters were found to be normally distributed with an Asympt-sig (2-tailed) value $>0.05$. Overall data that were normally distributed could be considered to be representative of the population, and further tests were carried out in the parametric test.

\section{Comparison of Morphometric Characters}

Comparison of crab morphometrics was estimated by using Kruskal Wallis test analysis (Table 3). The results of the analysis of BSC morphometrics at five locations showed a significant difference $(\mathrm{p}<0.05)$ in twenty-nine characters. This explains that the crab in East Lampung, Lancang Island, Cirebon, Rembang, and Southern Madura can be distinguished from the overall character. Differences in environmental conditions are thought to have a significant effect on differences in BSC morphometrics in FMA 712. The environmental 394 
condition influences the differences in morphometric characters and could affect the growth rate of a particular body part (Zairion et al., 2020). Changes in morphological characters become a form of adjustment for each organism to its environment (Pramithasari et al., 2017). Li et al. (2018) explains that differences in environmental conditions affect the adaptation patterns of a species. The differences in the morphology of a species are often occur due to environmental and geographical location differences (Hidayani et al., 2018). One of the most common forms of adaptation seen is the changes in the morphology and morphometry of the body. This statement is strengthened by Lai et al. (2010) saying that the adaptation form of an organism to external factors (habitat and food) is by changing its morphological character. The female crab in pre-molt phase that living in an environment with limit food availability had a lower growth than the crab with enough food (Josileen, 2011).

Table 3 Comparison of crab morphometric characters in Fisheries Management Area 712, Indonesia using t-

\begin{tabular}{ccc}
\multicolumn{4}{c}{ test at $\mathrm{p}=0.05$} & \\
\hline Code & Landmark & $\mathrm{p}$-value \\
\hline UP1 & $1-8$ & $6 \times 10^{-23}$ \\
UP2 & $3-13$ & $1 \times 10^{-23}$ \\
UP3 & $4-12$ & $4 \times 10^{-17}$ \\
UP4 & $5-11$ & $3 \times 10^{-13}$ \\
UP5 & $6-10$ & $3 \times 10^{-12}$ \\
UP6 & $7-9$ & $4 \times 10^{-27}$ \\
UP7 & $1-7$ & $1 \times 10^{-22}$ \\
D1 & $2-13$ & $1 \times 10^{-28}$ \\
D2 & $3-14$ & $8 \times 10^{-20}$ \\
D3 & $4-13$ & $9 \times 10^{-23}$ \\
D4 & $3-12$ & $5 \times 10^{-19}$ \\
D5 & $5-12$ & $2 \times 10^{-16}$ \\
D6 & $4-11$ & $2 \times 10^{-15}$ \\
D7 & $6-11$ & $2 \times 10^{-14}$ \\
D8 & $5-10$ & $2 \times 10^{-12}$ \\
D9 & $7-10$ & $8 \times 10^{-18}$ \\
D10 & $6-9$ & $2 \times 10^{-12}$ \\
L1 & $2-3$ & $5 \times 10^{-15}$ \\
L2 & $13-14$ & $2 \times 10^{-5}$ \\
L3 & $3-4$ & $4 \times 10^{-8}$ \\
L4 & $12-13$ & $1 \times 10^{-42}$ \\
L5 & $4-5$ & $8 \times 10^{-8}$ \\
L6 & $11-12$ & $6 \times 10^{-9}$ \\
L7 & $5-6$ & $9 \times 10^{-5}$ \\
L8 & $10-11$ & $4 \times 10^{-6}$ \\
L9 & $6-7$ & $3 \times 10^{-10}$ \\
L10 & $9-10$ & $3 \times 10^{-22}$ \\
L11 & $1-6$ & $1 \times 10^{-18}$ \\
L12 & $1-10$ & $1 \times 10^{-19}$ \\
\hline & &
\end{tabular}




\section{Portunus pelagicus Population Grouping}

The grouping of crab populations can be seen from the level of similarity among populations based on morphometric characters that are thought to use cluster analysis. The results of the crab cluster analysis are presented in the form of the dendrogram (Figure 3). The dendrogram formed will show the similarity of BSC from five locations in FMA 712. The BSC relationship among populations is explained in the results of cluster analysis. The results of cluster analysis of five crab populations formed two groups, namely the crab population group of Lancang Island-Cirebon-East Lampung-Rembang crab population group, and the Southern Madura crab group. BSC located in Southern Madura formed their own group into the second group with low similarity with BSC populations in four other locations. However, BSC located in the area of East Lampung, Rembang, Lancang Islang, and Cirebon have the same similarity and form one group. This similarity in closely geographical location was related to similar environments. However, East Lampung-Rembang crabs, which are geographically separated populations, have morphological similarity. This result might be due to local migration between connected locations (Hossain et al., 2010) or the similar ecological impacts (Mir et al., 2013).

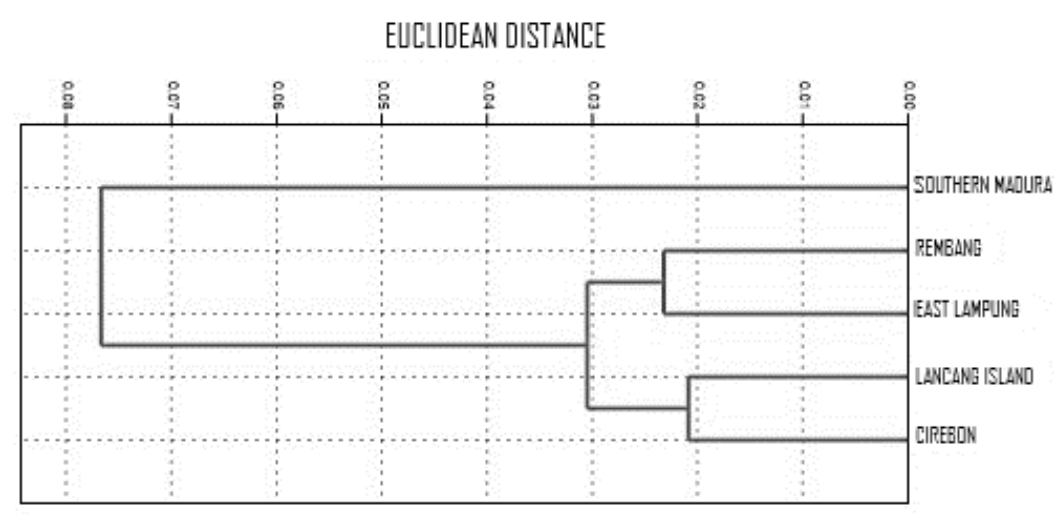

Figure 3 Cluster analysis of inter-population of blue swimming crab (Portunus pelagicus) in Fisheries Management Area 712, Indonesia

Based on the Euclidean distance, the higher the level of population similarity of organisms within the group will be higher. Things that cause grouping among populations include proximity of geographical locations (Abinawanto et al., 2018) and similar environmental conditions among locations (Solomon et al., 2015; Abinawanto et al., 2018; Zairion et al., 2020). The environmental conditions that might play important role for blue swimming crab are temperature, light intensity, and photoperiod vary seasonally among locations where the crab lives (Hamid et al., 2016b). Green et al. (2014) explain that crabs are shaped by environmental variation through the distribution ecology, productivity or even their market traits such as colour and size. The Euclidean distance among small populations is presented in Table 4.

Table 4 The Euclidean distance among population of blue swimming crab (Portunus pelagicus) in Fisheries Management Area 712, Indonesia

\begin{tabular}{lccccc}
\hline $\begin{array}{c}\text { Euclidean } \\
\text { Distance }\end{array}$ & East Lampung & Lancang Island & Cirebon & Rembang & Southern Madura \\
\hline East Lampung & 0 & 0.0365 & 0.0267 & 0.0232 & 0.073 \\
Lancang Island & 0.0365 & 0 & 0.0209 & 0.0311 & 0.0839 \\
Cirebon & 0.0267 & 0.0209 & 0 & 0.0276 & 0.0680 \\
Rembang & 0.0232 & 0.0311 & 0.0276 & 0 & 0.0817 \\
Southern Madura & 0.073 & 0.0839 & 0.0680 & 0.0817 & 0 \\
\hline
\end{tabular}




\section{Morphometric Character Classification}

Morphometric character classification at each location was assumed to use discriminant analysis. Discriminant analysis showed that the grouping of characters formed was marked by differences in the location of centroids. The crab morphometric character classification (Figure 4) shows that there are three centroid centers in five locations of FMA 712. The crab morphometric character distribution at each location shows the level of closeness to other locations. The crab character from Lancang Island has an adjacent centroid point, and the characters are not completely separated from the crab character from Cirebon, which means it has the same size between characters. The BSC in these two locations are significantly separated from the BSC in East Lampung and Rembang, while the BSC in southern madura is not completely separated. The BSC population in East Lampung is not completely separated from the BSC population in Rembang. Yet it is significantly separated from the other three locations. This indicates the level of morphological similarity in the BSC population at that location (Marini et al., 2017).

Figure 4 showed that Function 1 successfully discriminated the individuals into three separate groups. Muchlisin (2013) saying that the presence of contact among populations indicate the closeness of population groups. The point of intersecting population indicates that the population has a close kinship. Abinawanto et al. (2018) state that the overlap among morphometric characters of the two populations shows the high morphological similarity. The BSC in East Lampung, and Rembang were significantly separated and significantly different from the BSC in 3 other locations. This shows that there are different habitat preferences in an organism that can affect population structure. Zimmerman et al. (2011) and Hepp et al. (2012) explain that adaptations frequently encompass changes in morphology, such as in the size and shape of the carapace or cheliped or in individual condition. Zairion et al. (2020) explain that BSC was able to adapt in habitats with variation environmental parameters. It's indicated that BSC was able to live in a high variation of environment, such as in dry season even in low proportion (Supadminingsih et al., 2019).

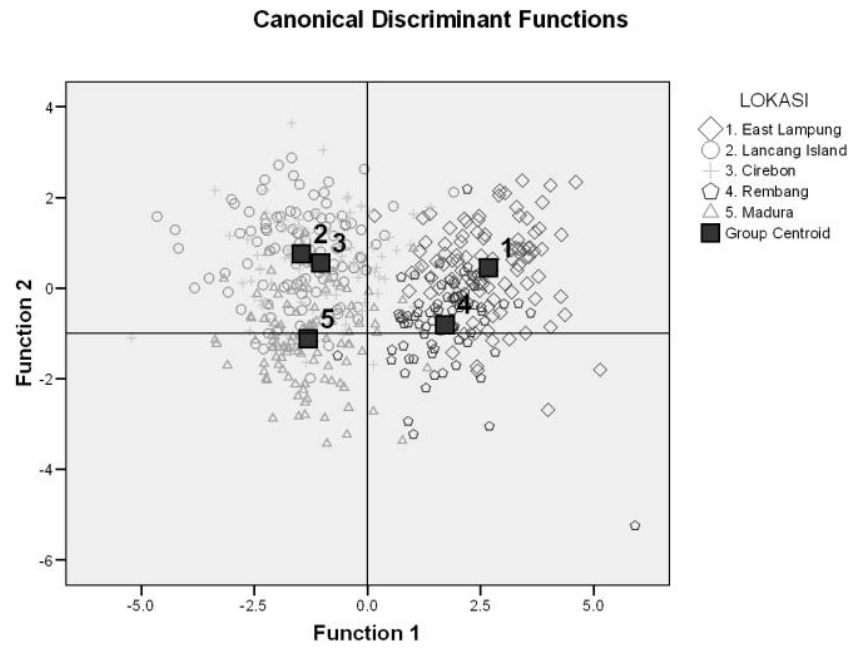

Figure 4 Canonical distribution analysis using morphometric characters of blue swimming crab (Portunus pelagicus) collected from five sites in Fisheries Management Area 712, Indonesia

Percentage of BSC population from East Lampung waters, Lancang Island, Cirebon, Rembang, and Southern Madura has been classified as $84.8 \%, 62.3 \%, 62 \%, 87.7 \%$, and 75.2\%, respectively (Table 5). More than half of the population from East Lampung can describe the location of Rembang marked by a group point of one location that is in another location group. According to Marini et al. (2017), a percentage value of $>80 \%$ indicates that the population of the BSC group at one location truly characterizes the blue swimming crab group from another population group. 
Table 5 Results of blue swimming crab population grouping in Fisheries Management Area 712, Indonesia from five locations due to discriminant analysis

\begin{tabular}{lccccc}
\hline & \multicolumn{3}{c}{ Prediction Group } \\
\cline { 2 - 6 } & $\begin{array}{c}\text { East } \\
\text { Lampung }\end{array}$ & Lancang Island & Cirebon & Rembang & Southern Madura \\
\hline East Lampung & 84.85 & 1.01 & 0 & 14.14 & 0 \\
Lancang Island & 0.94 & 62.26 & 22.64 & 0 & 14.15 \\
Cirebon & 2.17 & 20.65 & 61.96 & 5.43 & 9.78 \\
Rembang & 10.96 & 0 & 0 & 87.67 & 1.37 \\
Southern Madura & 0.95 & 11.43 & 7.62 & 4.76 & 75.24 \\
\hline
\end{tabular}

\section{CONCLUSION}

Based on morphometric characters, population of blue swimming crab (BSC) Portunus pelagicus from the southern Madura had a low level of similarity with the other four BSC populations. It is recommended to consider the Southern Madura crab as a separate sub division in the management of crab fisheries in FMA 712. It is also recommended to create the sub management area in FMA 712 that manages the BSC in Southern Madura separately. The sub management area of FMA 712 could help stakeholders to establish best strategies for sustainable use of the BSC.

\section{ACKNOWLEDGEMENTS}

This paper is part of our research work funded by the Directorate General of Research and Development Reinforcement, Ministry of Technology Research and Higher Education for a research grant in accordance with the Letter of Appointment for Research Program Implementation Number: 1728/IT3.11/PN/2018. The first author would like to thank Alvia, Fauziyyah, Denanda, Bagus, and Dinda for their assistance in the field and laboratory works.

\section{REFERENCES}

Abinawanto, Hamidah H, Bowolaksono A, Eprilurahman R. 2018. Short communication: biometric of freshwater crayfish (Cherax spp.) from Papua and West Papua, Indonesia. Biodiversitas. 19(2): 489495. doi: 10.13057/biodiv/d190216.

Aini NK, Mashar A, Madduppa HH, Wardiatno Y. 2020. Genetic diversity of horseshoe crabs (Carcinoscorpius rotundicauda and Tachypleus gigas) in Demak, Madura and Balikpapan waters based on Random Amplified Polymorphic DNA marker. Journal of Natural Resources and Environmental Management. 10(1): 124-137. doi: 10.29244/jpsl.10.1.124-137.

Bhosale MM, Pawar RA, Bhendarkar MP, Sawant MS, Pawase AS. 2018. Truss based morphometric approach for the analysis of body shape in portunid crabs (Charybdis feriatus, $P$. pelagicus and $P$. sanguinolentus) along Ratnagiri coast, India. Journal Entomology Zoology Studies. 6(2): 2641-2648.

FAO (Food and Agriculture Organization). 1995. Code of Conduct for Responsible Fisheries. Rome (IT): FAO Technical Guidelines for Responsible Fisheries.

Ghasemi A, Zahediasl S. 2012. Normality tests for statistical analysis: a guide for non-statisticians. Int $J$ Endocrinol Metab. 10(2): 486-489. doi: 10.5812/ijem.3505.

Green BS, Gardner C, Hochmuth JD, Linnane A. 2014. Environmental effects on fished lobster and crabs. Rev Fish Biol Fisheries. 24(2): 613-638. doi: 10.1007/s11160-014-9350-1.

Hamid A, Wardiatno Y. 2015. Population dynamics of the blue swimming crab (Portunus pelagicus Linnaeus, 1758) in Lasongko Bay, Central Buton, Indonesia. AACL Bioflux. 8(5): 729-739. 
Hamid A, Wardiatno Y, Lumban Batu DTF, Riani E. 2015. Fecundity and gonad maturity stages of ovigerous female blue swimming crab (Portunus pelagicus) in Lasongko Bay, Southeast Sulawesi. Bawal. 7(1): 43-50.

Hamid A, Wardiatno Y, Djamar TFLB, Riani E. 2016a. Stock status and fisheries exploitation of blue swimming crab Portunus pelagicus (Linnaeus 1758) in Lasongko Bay, Central Buton, Indonesia. Asian Fish Sci. 29(4): 206-219.

Hamid A, Batu DTFL, Riani E, Wardiatno Y. 2016b. Reproductive biology of blue swimming crab (Portunus pelagicus Linnaeus, 1758) in Lasongko Bay, Southeast Sulawesi-Indonesia. AACL Bioflux. 9(5): 10531066.

Hammer O, Harper DAT, Ryan PD. 2001. PAST: paleontological statistics software package for education and data analysis. Palaeontologia Electronica. 4(1): 1-9.

Hart PJB, Reynolds JD. 2002. Handbook of Fish Biology and Fisheries: Fish Biology. Oxford (UK): Blackwell Publishing.

Hepp LU, Fornel R, Restello RM, Trevisan A, Santos S. 2012. Intraspecific morphological variation in a freshwater crustacean Aegla Plana in Southern Brazil: effects of geographical issolation on carapace shape. Journal of Crustacean Biology. 32(4): 511-518. doi: 10.1163/193724012X630660.

Hidayani AA, Fujaya Y, Asphama AI, Trijuno DD, Tenriulo A, Parenrengi A. 2015. The morphometric character and mitochondrial 16S rRNA sequence of Portunus pelagicus. Aquacultura Indonesiana. 16(1): 1-9. doi: 10.21534/ai.v16i1.1.

Hidayani AA, Trijuno DD, Fujaya Y, Alimuddin, Umar MT. 2018. The morphology and morphometric characteristics of the male swimming crab (Portunus pelagicus) from the East Sahul Self, Indonesia. AACL Bioflux. 11(6): 1724-1736.

Hollander J, Butlin RK. 2010. The adaptive value of phenotypic plasticity in two ecotypes of a marine gastropod. BMC Evol Biol. 10(1): 333-340. doi: 10.1186/1471-2148-10-333.

Hossain MAR, Nahiduzzaman M, Saha D, Khanam MUH, Alam MS. 2010. Landmark-based morphometric and meristic variations of the endangered carp, Kalibaus Labeo calbasu, from stocks of two isolated rivers, the Jamuna and Halda, and a hatchery. Zool Stud. 49(4): 556-563.

Hurlbut T, Clay D. 1998. Morphometric and meristic differences between shallow and deep-water populations of white hake (Urophycis tenuis) in the southern Gulf of St. Lawrence. Can J Fish Aquat Sci. 55: 22742282. doi: 10.1139/cjfas-55-10-2274.

Ihsen PE, Booke HE, Casselman JM, Mc Glade JM, Payne NR, Utter FM. 1981. Stock identification materials and methods. Can J Fish Aquat Sci. 38: 1838-1855. doi: 10.1139/f81-230.

Jayawiguna MH, Mulyono M, Nugraha E, Prayitno H, Basith A. 2017. Biology aspect of blue swimming crab (Portunus pelagicus) in Jakarta Bay Waters, Indonesia. Aust J Basic App Sci. 11(13): 63-67. doi: 10.15578/bawal.8.1.2016.13-20.

Josileen J. 2011. Morphometrics and length-weight relationship in the blue swimmer crab Portunus pelagicus (Linnaeus, 1758) (Decapoda, Brachyura) from The Mandapam, Coast India. Crustaceana. 84(14): 16651681. doi: 10.1163/156854011X607060.

Kembaren DD, Zairion, Kamal MM, Wardiatno Y. 2018. Abundance and spatial distribution of blue swimming crab (Portunus pelagicus) larvae during east monsoon in the East Lampung waters, Indonesia. Biodiversitas. 19(4): 1326-1333. doi: 10.13057/biodiv/d190420.

Lai JCY, Ng PKL, Davie PJF. 2010. A revision of the Portunus pelagicus (Linnaeus, 1758) species complex (Crustacea: Brachyura: Portunidae), with the recognition of four species. Raffles Bulletin of Zoology. 58(2): 199-237.

Li S, Cui B, Xie T, Bai J, Wang Q, Shi W. 2018. What drives the distribution of crab burrows in different habitats of intertidal salt marshes, Yellow River Delta, China. Ecol Indic. 92: 99-106. doi: 10.1016/j.ecolind.2017.11.003. 
Marini M, Suman A, Farajallah A, Wardiatno Y. 2017. Identifying Penaeus merguiensis de Man, 1888 stocks in Indonesian Fisheries Management Area 573: a truss network analysis approach. AACL Bioflux. 10(4): 922-935.

Ministry of Marine Affairs and Fisheries (MMAF). 2018. Crab Export in 2014-2018. Jakarta (ID): Direktorat Jenderal Penguatan Daya Saing Produk Kelautan dan Perikanan.

Mir JI, Sarkar UK, Dwivedi AK, Gusain OP, Jena JK. 2013. Stock structure analysis of Labeo rohita (Hamilton, 1822) across the Ganga basin (India) using a truss network system. J Appl Ichthyol. 29: 10971103. doi: 10.1111/jai.12141.

Mishra P, Pandey CM, Singh U, Gupta A, Sahu C, Keshri A. 2019. Descriptive statistics and normality test for statistical data. Annals of Cardiac Anaesthesia. 22(1): 67-72. doi: 10.4103/aca.ACA_157_18.

Mojekwu TO, Anumudu CI. 2015. Advanced techniques for morphometric analysis in fish. J Aquac Res Develop. 6(8): 1-6. doi: 10.4172/2155-9546.1000354.

Muchlisin ZA. 2013. Morphometric variations of Rasbora Group (Pisces: Cyprinidae) in Lake Laut Tawar, Aceh Province, Indonesia, based on truss character analysis. Hayati J Biosci. 20(3): 138-143. doi: 10.4308/hjb.20.3.138.

Ostertagova E, Ostertag O, Kovac J. 2014. Methodology and application of the Kruskal Wallis test. Appl Mech Mater. 611: 115-120. doi: 10.4135/9781412961288.n207.

Paramasivam P, Chakraborty RD, Ganesan K, Maheswarudu G. 2017. Stock structure analysis of 'Aristeus alcocki Ramadan, 1938 (Decapoda: Aristeidae)' in the Indian coast with truss network morphometrics. Can J Zool. 96(5): 411-424. doi: 10.1139/cjz-2016-0283.

Pazhayamadom DG, Chakraborty SK, Jaiswar AK, Sudheesan D, Sajina AM, Jahageerdar S. 2015. Stock structure analysis of "Bombay duck" (Harpadon nehereus Hamilton, 1822) along the Indian coast using truss network morphometrics. J Appl Ichthyolo. 31: 37-44. doi: 10.1111/jai.12629.

Prabawa A, Riani E, Wardiatno Y. 2014. The influence of heavy metals contamination to the population structure and organs of the blue swimming crab (Portunus pelagicus, LINN). Journal of Natural Resources and Environmental Management. 4(1): 17-23. doi: 10.29244/jpsl.4.1.17.

Pramithasari FA, Butet NA, Wardiatno Y. 2017. Variation in morphometric characters in four sand crab (Albunea symmysta) populations collected from Sumatra and Java Island, Indonesia. Trop Life Sci Res. 28(1): 103-115. doi: 10.21315/tlsr2017.28.1.7.

Rawat S, Benakappa S, Kumar J, Naik K, Pandey G, Pema CW. 2017. Identification of fish stock based on truss morphometric: a review. J Fish Life Sci. 2(1): 9-14.

Rebello VT, George MK, Paulton MP, Sathianandan TV. 2013. Morphometric structure of the jumbo tiger prawn, Penaeus monodon Fabricius, 1798 from southeast and southwest coasts of India. J Mar Biol Assoc India. 55(2): 11-15. doi: 10.6024/jmbai.2013.55.2.01784-02.

Rohlf FJ. 2006. Tps Dig2, version 2.1. State University of New York Stony Brook, NY [Internet]. [cited 2018 Dec 5]. Available from: http.//life.bio.sunysb.edu/morph/.

Sajina AM, Chakraborty SK, Jaiswar AK, Pazhayamadam DG, Sudheesan D. 2011. Stock structure analysis of Megalaspis cordyla (Linnaeus, 1758) along the Indian coast based on truss network analysis. Fish Res. 108: 100-105. doi: 10.1016/j.fishres.2010.12.006.

Secor DH. 2014. The Unit Stock Concept: Bounded fish and fisheries. In: Stock Identification Methods. San Diego (US): Academic Press.

Sen S, Jahageerdar S, Jaiswar AK, Chakraborty SK, Sajina AM, Dash GR. 2011. Stock structure analysis of Decapterus russelli (Ruppell, 1830) from east and west coast of India using truss network analysis. Fish Res. 112: 38-43. doi: 10.1016/j.fishres.2011.08.008.

Smith SL, Pollnac RB, Colburn LL, Olson J. 2011. Classification of coastal communities reporting commercial fish landings in the U.S. northeast region: developing and testing a methodology. Mar Fish Rev. 73(2): 41-61. 
Statistics Indonesia (SI). 2018. Export of crabs and shellfish by major destination countries in 2002-2015. Jakarta (ID): Sensus Pertanian BPS.

Solomon SG, Okomoda VT, Ogbenyikwu AI. 2015. Intraspecific morphological variation between cultured and wild Clarias gariepinus (Burchell) (Clariidae, Siluriformes). Arch Pol Fish. 23: 53-61. doi: 10.1515/aopf-2015-0006.

Supadminingsih FN, Wahju RI, Riyanto M. 2019. Composition of blue swimming crab Portunus pelagicus and horshoe crab Limulidae on the gillnet fishery in Mayangan Waters, Subang, West Java. AACL Bioflux. 12(1): 14-24.

Wiyono ES, Ihsan. 2015. The dynamic of landing blue swimming crab (Portunus pelagicus) in Pangkajene Kepulauan, South Sulawesi, Indonesia. AACL Bioflux. 8(2): 134-141.

Wiyono ES, Ihsan. 2018. Abundance, fishing season and management strategy for blue swimming crab (Portunus pelagicus) in Pangkajene Kepulauan, South Sulawesi, Indonesia. Trop Life Sci Res. 29(1): 115. doi: 10.21315/tlsr2018.29.1.1.

Zairion, Wardiatno Y, Boer M, Fahrudin A. 2015a. Reproductive biology of the blue swimming crab Portunus pelagicus (Brachyura: Portunidae) in east Lampung waters, Indonesia: fecundity and reproductive potential. Trop Life Sci Res. 26(1): 67-85.

Zairion, Wardiatno Y, Fahrudin A. 2015b. Sexual maturity, reproductive pattern and spawning female population of the blue swimming crab, Portunus pelagicus (Brachyura: Portunidae) in east Lampung coastal waters, Indonesia. Indian J Sci Tech. 8(6): 596-607. doi: 10.17485/ijst/2015/v8i6/69368.

Zairion, Fauziyah, Riani E, Hakim AA, Mashar A, Madduppa H, Wardiatno Y. 2020. Morphometric character variation of the blue swimming crab (Portunus pelagicus Linnaeus, 1758) population in western and eastern part of Java Sea. IOP Conf. Series: Earth and Environmental Science. doi: 10.1088/17551315/420/1/012034.

Zimmerman G, Bosc P, Valade P, Cornette R, Ameziane N, Debat V. 2011. Geometric morphometrics of carapace of Macrobrachium australe (Crustacea: Palaemonidae) from Reunion Island. Acta Zoologica (Stockholm). 93: 492-500. doi: 10.1111/j.1463-6395.2011.00524.x. 